\title{
The Roman Suburb on the Vrina Plain Outside Butrint, Albania
}

Luigi Maria Ugolini identified the suburb at Phoinike but not at Butrint. This short essay in honour of Sandro De Maria summarizes the early Roman archaeological sequence of the suburb identified and excavated by the Butrint Foundation between 2000-7. The unfortified suburb grew up around a multiarched bridge over the Vivari channel. It was initially a settlement of small dwellings and shops, before it was aggregated to become a substantial channelside villa (like those within the walled enclosure of Butrint).

To Sandro De Maria with esteem and affection.

I first met Sandro De Maria at Phoinike where he excavated on the hilltop and in its suburb at the bottom of the hill. We both shared a great admiration for the work of Luigi Maria Ugolini whose Italian Archaeological Mission first excavated at Phoinike before transferring its focus to Butrint in 1928. Curiously, Ugolini recognized the suburb at Phoinike, but not at Butrint. This brief essay describes the beginnings of Butrint's suburb as a bridgehead in Roman times, part of a study that owes much to the stimulating conversations between the Butrint Foundation team with Sandro and his colleagues from the University of Bologna.

The stratified archaeology of the early Imperial settlement on the Vrina Plain outside the ancient city of Butrint, Buthrotum, is intriguing, begging many new questions. Following a field survey (1995-96) reaching back to the villages outside of Butrint, Mursi and Xarra, a large-scale geophysical survey and an equally extensive assessment excavation, as well as four large excavations (aggregated in three areas) have been undertaken on the Vrina Plain'. Excavations by the Butrint Foundation in collaboration with the Institute of Archaeology of Tirana between 2002-7 focused upon (1) the northern terminus of the road crossing the plain and certain of the areas either side of it, in one case extending as far east as the early Imperial

1 See a review of the field surveys between 1994-2009 in Hodges et alii 2016. 
aqueduct running parallel to the road; (2) the large occupied area to the west of the road occupying a low hill beside a palaeo-channel leading into the Vivari Channel; (3) discrete areas to the east of the aqueduct where a solitary residence and several mausolea have been found. Given the large scale of these excavations, it will be some years before their full importance is grasped in relation to the archaeology of the early Roman period within the town of Butrint ${ }^{2}$. Nevertheless, some critical elements pertinent to the evolving topographical history are already apparent. Perhaps the most striking outcome is the absence of evidence of the Roman colony at Butrint, apparently established by Julius Caesar and re-established after the batthe of Actium during the early years of Augustus's long reign. ${ }^{3}$ On the other hand, the archaeology does chart the steady growth of the suburban settlement during the 1st and 2nd centuries $\mathrm{AD}$, when, confined by its location on a promontory reaching into the south side of the Vivari channel, this formed a substantial appendage to the fast expanding town of Butrint on the south side of the major bridge leading to the town ${ }^{4}$.

\section{The colony}

There can be little doubt that a colony of some form was created at Butrint in the later 1st century BC. ${ }^{5}$ The textual evidence, especially the epigraphy, reveals an imperial intervention that owed much to the town's relationship to Agrippa, Augustus's victorious general at Actium: ${ }^{6}$ Agrippa's first wife was the daughter of Titus Pomponius Atticus, a major landowner close to Butrint in late Republican times, and an active proponent of the town. The question is what impact did the colony have upon the pre-existing late Hellenistic town? For sure, the civic centre of Butrint was extensively reorganized with a new paved forum being imposed over the earlier agora, causing a tract of the sanctuary town's Hellenistic fortifications to be dismantled. Associated with this grand new intervention were several major buildings as well as a number of major statues, indicative of the town's connections to the Imperial court in Rome. ${ }^{8}$ The aqueduct from Xarra and the road bridge across the Vivari Channel are other examples of significant investment in infrastructure that probably date to this moment. Both, it has been argued, were depicted on one type of Butrint's coinage minted from the inception of the colony

\footnotetext{
2 See Hernandez 2017b.

3 Cf. Hansen 2011.

4 See Leppard 2013.

5 Cabanes, Drini and Hatzopoulos 2007, p. 249; De Maria 2007; Deniaux 1998, 2007, 2009: 1720; Hansen 2007, 2011; Hernandez and Çondi 2008, 2014; Giorgi 2017; Bowden 2020.

6 Hansen 2007, 2009, 2011.

7 Hernandez and Çondi, 2014. Hernandez 2017b.

8 Hansen 2007, 2013.
} 
through to the reign of the Emperor Nero. ${ }^{9}$ However, no such evidence exists for either town-houses of this early Imperial period between the Hellenistic wall and the Vivari Channel or indeed on the Vrina Plain. Nor is there yet any evidence of landfill beside the Vivari Channel, such as was found in the 11th century AD, to facilitate the construction of channel side buildings. ${ }^{10}$ Admittedly the opportunity to excavate down to reach Hellenistic levels beside the Vivari Channel in the large Triconch Palace excavations was greatly inhibited by waterlogging," but the absence of any diagnostic ceramics from these excavations is telling. Beyond the Vivari channel, only beside the section of road excavated on the Vrina Plain and in the area of the outlying residential house ${ }^{12}$ within the later cemetery zone were small amounts of late Republican wares present, possibly associated with smallscale domestic habitation on the plain.

It now appears that the early Imperial town was contained within the earlier fortified, Hellenistic area, and only as the enlarged community prospered during the Flavian era, as illustrated by the coins found in the Vrina Plain excavations in Phase 1 , was the bridgehead settlement episodically then systematically occupied ${ }^{13}$. Other suburban settlements probably date from this period, too (Fig. 1). For example, there are traces of Roman period settlement beneath the Venetian Triangular Castle discovered during the geophysical survey.${ }^{14}$ Likewise, on Shën Delli, the hill behind the Vrina Plain settlement, traces of Roman settlement were found in the 2008 survey. ${ }^{15}$

It is also worth noting that on the east shore of Lake Butrint, the Hellenistic and Augustan villa at Diaporit, was extensively rebuilt on a new alignment in the period $\mathrm{AD}$ 40-80 with the new substantial waterfront villa angled to look across the lake towards Butrint, as opposed to looking out over the lake towards the village of Ksamili to the west and Phoinike to the north. ${ }^{16}$ Elsewhere within the hinterland of Butrint, it will be interesting to learn the chronology of the diminutive maritime villa at the entrance to the Vivari Channel, and the settlement at the north end of Alinura Bay.

9 Abdy 2012: 91-92.

10 Cf. Hodges 2016.

11 Cf. Bowden and Hodges 2011.

12 Gilkes and Hysa 2011.

13 Greenslade 2019a, 2019b provide the detail for much of what follows in this essay.

14 Cf. Crowson 2008: 49 (top figure).

15 Hodges et alii 2016.

16 Bowden and Përzhita 2004. 


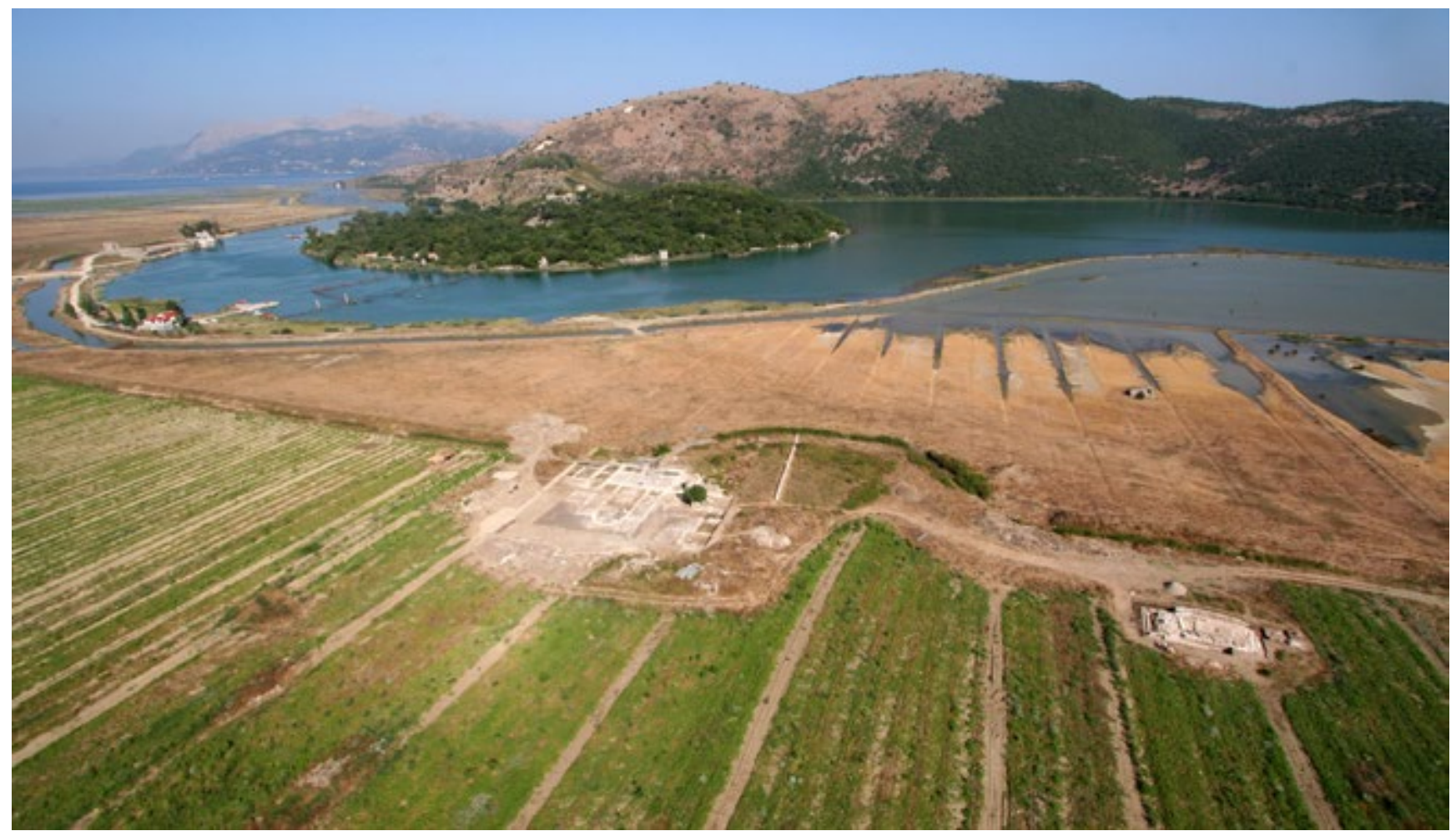

Fig. 1. Aerial shot of the excavations looking west across Butrint towards the Straits of Corfu (photo: Alket Islami)

\section{The suburb and centuriation}

The road leading up to the bridgehead was a key element in the making of the Vrina Plain settlement. Bescoby has argued that there were at least two road alignments: one that pre-dates the settlement and one, excavated ${ }^{17}$, that certainly belonged to the 1st century and ran across the drained plain by the most direct route through the new Vrina Plain settlement to the embarkation point leading to the Tower Gate in Butrint's Hellenistic wall circuit. The early road almost certainly had some antiquity, earlier than the first century $\mathrm{AD}$, and hypothetically may date back to the Archaic Greek period or later prehistory. Bescoby speculates that the original pre-Roman road followed the low hills to Shën Dimitri, then pursued the south side of the channel to a point of embarkation close to a promontory reaching into the Vivari Channel, and close to a pebble bar in the channel. He believes that this early road followed a line from Çuka i Aitoit, via Mursi, anchored on a peak of Mt. Sotirës.

The approximate direction of a major bridge across the Vivari Channel, almost certainly dating from this time, is known from a small surviving section on the north bank. ${ }^{18}$ Unfortunately, there is no trace of the road immediately south of the bridge, but it was almost certainly anchored on the pebble bar described above.

\footnotetext{
17 Bescoby 2007; see now Hernandez 2017a: 241.

18 Leppard 2013.
} 
Did the road running south from the bridge follow the alignment or create the alignment for the centuriation? It is simply not possible presently to determine this. The piers of the aqueduct appear to follow an alignment within the grid of the proposed centuriation. ${ }^{19}$

The aqueduct almost certainly took the most direct route across the reclaimed land on the Vrina Plain from a spring close to the modern village of Xarra to a header tank positioned on the edge of the Vivari Channel. It was supported on brick-built piers as far as a header tank that lay just to the north of the pebble bar described above. From the header tank, the aqueduct was possibly piped along the roadbridge into Butrint. ${ }^{20}$ The archaeology of the aqueduct indicates that it formed part of the early imperial initiative in the civic centre of Butrint, bringing fresh water to augment the water from Butrint's wells. The excavations did not establish how early a branch from this supplied the Vrina Plain settlement, although it is likely to have been in Phase 2; as yet, no wells of this period have been found on the promontory.

The Vrina Plain suburb coalesced around a road running eastwards from the bridgehead, just east of a north-south palaeo-channel off the Vivari Channel, which possibly provided safe harbourage off of the Vivari Channel (Fig. 2). In the Flavian period, if not before (though Julio-Claudian ceramics and coins are absent), a series of houses of varying sizes were located within a grid of at least four insulae separated by newly made gravelled roads. Some of these houses incorporated shops fronting onto the roads. The angle of its grid of streets, running 6 degrees off that of the cardinal line of the centuriation suggests that other local elements determined its precise location. As part of this expansion a new residential building with associated bath-house was built on the channel edge c. $400 \mathrm{~m}$ to the east of the suburb. ${ }^{21}$

There is little doubt that the changing relationship between the land and water table meant that more land was accessible from the later Hellenistic period until the later Roman period than had been the case previously.22 Much of this land, of course, would have been seasonally marshy much as can be seen today. This was the context for the new settlement on the Vrina Plain. It may have owed much to the extensive clearance of the adjacent hill slopes in the later first millennium, leading to episodic colluviums being washed down towards the plain. Certainly, the one palynological record from close by at Lake Bufi shows a sudden drop in oak pollen in this era, suggesting extensive land clearance. ${ }^{23}$ Was there then a program-

19 See Bescoby 2007; Wilson 2013.

20 Cf. Wilson 2013: 85-86; fig. 5.14. See also De Maria 2007.

21 Gilkes and Hysa 2011.

22 Morellón et al 2016.

23 Lane 2004: 42-43; see also Morellon et al 2016. 


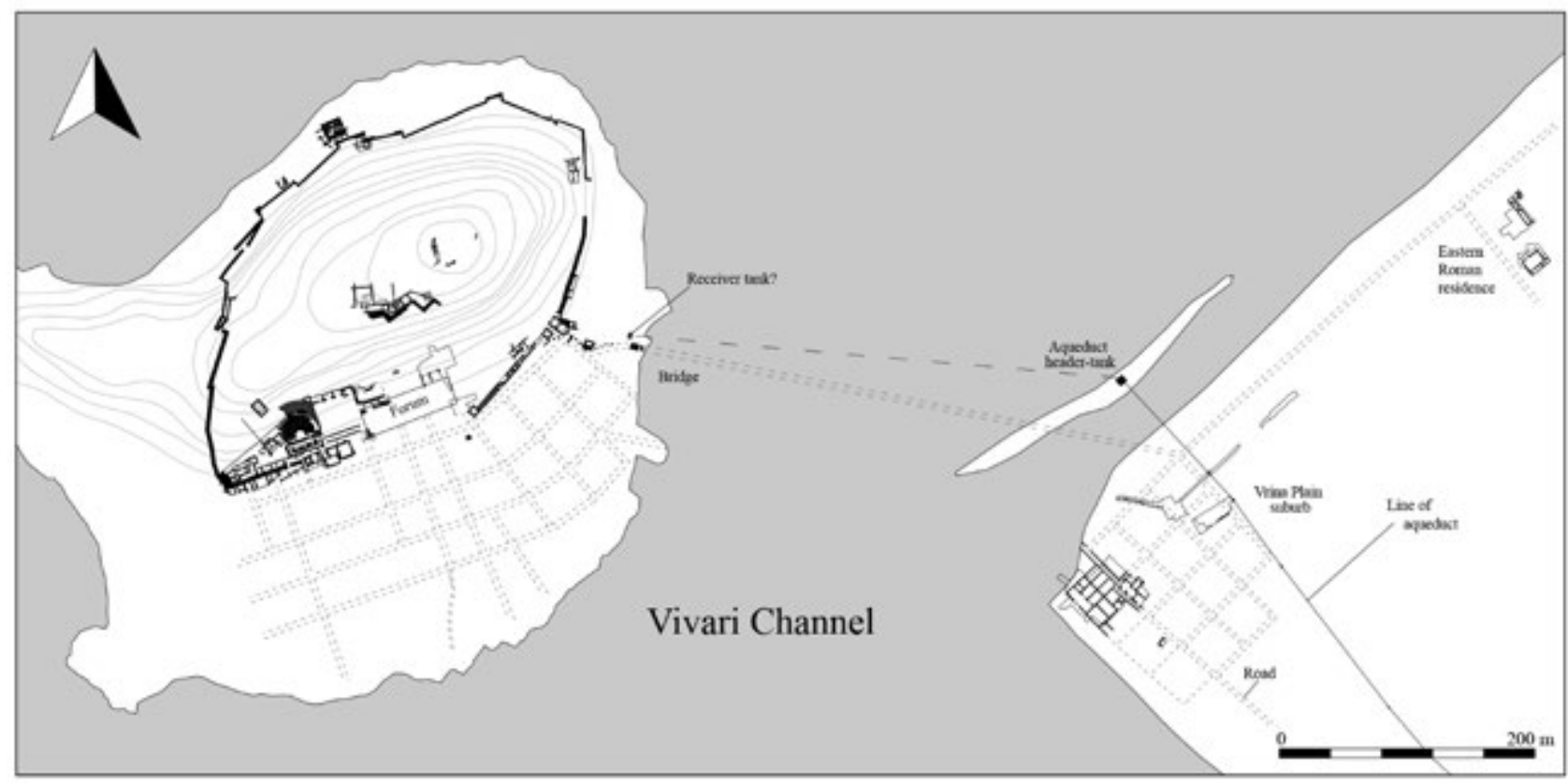

Fig. 2. A general plan showing Butrint, the bridge, the excavated area on the Vrina Plain in the 1st century $A D$ (drawn by Simon Greenslade)

me of land reclamation, perhaps with dykes and land-fill, the latter being a prominent feature of the re-making of the 11th-century Byzantine town when the problems of the rising water-table needed to be met?24 No dykes and no evidence of land-fill have been discovered as yet, although a possible late Republican to early Imperial make-up level appears to underlie the outlying villa found far to the east of the principal road..$^{25}$ Such land reclamation works are well known from the Roman Empire, but the evidence at Butrint remains to be indubitably demonastrated.

According to Bescoby, the Archaic and Hellenistic settlement of Çuka i Aitoit and a peak on Mount Sotirës, north-west of Butrint, served as the cardinal line for surveying and laying out the landscape of fields. The fields themselves were parcelled within a 20 by 20 actus grid $^{26}$ - a comparatively common formula in Greece at this time. ${ }^{27}$ Bescoby, however, has speculated that 'traces of another set of land divisions following the same alignment, but conforming to units divisible by 12 and 16 actus also was detected' (Fig. 3). ${ }^{28}$ He proposed that this could relate to an earlier system of division. Unfortunately, no archaeological dating exists for either system. Ground-truthing and associated excavations of farmhouses within the centuriated landscape is now needed to definitively ascertain its form and chronology. Both systems, however, if they actually existed, appear to belong to the

\footnotetext{
24 Bowden and Hodges 2011; Hodges 2016.

25 Gilkes and Hysa 2011.

26 Bescoby 2007: 113.

27 Bowden 2007: 198; Romano 2003.

28 Bescoby 2007: 113.
} 
mid 1st - to late 2nd -century AD management of the Vrina Plain by a multitude of property owners as opposed to the emergence in the late 2 nd century of a major property owner on this side of the channel. ${ }^{29}$

With the intensification of agriculture, unsurprisingly the second phase of the suburb dating to the 2nd century involved in-filling, either with the construction of new well-appointed properties or by up-dating existing buildings (Fig. 4). By this time a branch of the aqueduct served a cistern in the community, indicating an investment at the bridgehead matching that previously available within Butrint. Contained by the extent of the promontory with the palaeo-channel on the west side, this was now a suburb in the strict sense. The field survey and subsequent geophysical survey suggest that at its zenith it occupied about 1-2 hectares. ${ }^{30}$ Presumably, its cemetery lay along the shoreline

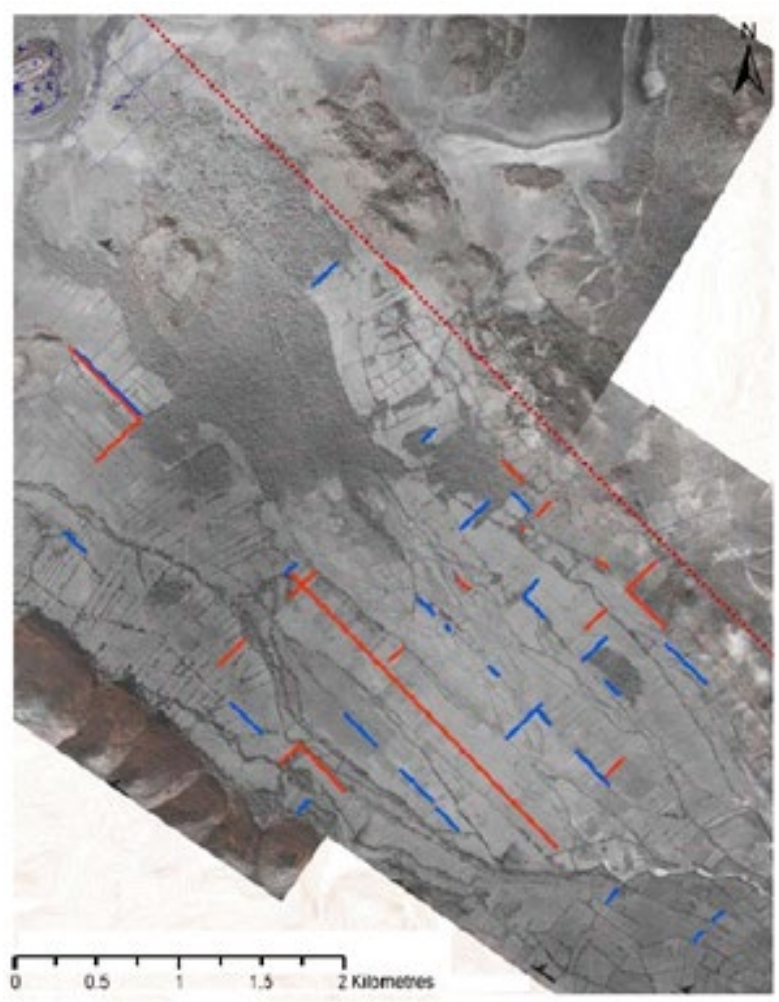

Fig. 3. Two periods of centuriation at Butrint based on a 1943 RAF aerial photograph (courtesy of David Bescoby)

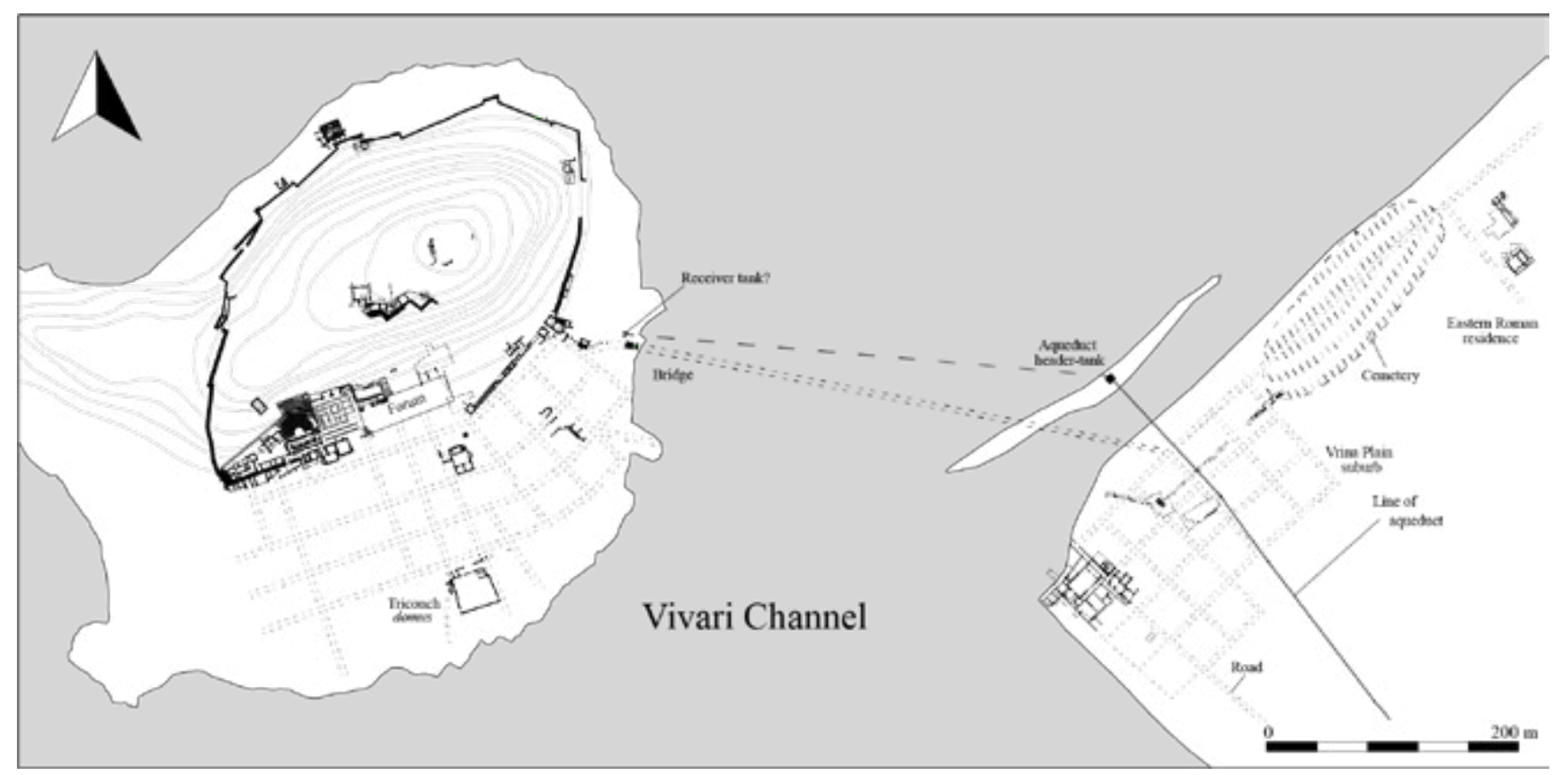

Fig. 4. General plan of the suburb on the Vrina Plain in the 2nd century (drawn by Simon Greenslade)

29 Cf. Hodges et alii: 2016.

30 Bescoby 2007, fig. 7.7. 
road reaching to Shën Dimitri. ${ }^{31}$ Connected to it were other outlying properties on the exposed hilltop of Shën Delli, half a kilometre to the east of the suburb, while the earlier residence on the shore edge in this area also continued to be occupied and developed. ${ }^{32}$ As was noted above, traces of another putative suburb were also found in the geophysical survey around the Venetian Triangular Castle outside Butrint, a kilometre to the west, at a point where the river Pavlass onc flowed into the Vivari Channel.

The growth of Roman settlement outside Butrint is undeniable, but phases 1 and 2 of this suburb belonging to the 1 st and 2 nd centuries were hardly affluent. Moreover, their material orientation, if it has any distinctive character, looked to Italy and Rome. The range of ceramics, mostly from the later 1st and 2nd centuries, was limited, with local imitations, Italian wares and Pontic sigillata. The majority of early Roman coins from the suburb are Roman Provincial issues. Only two preFlavian imperial issues, two poorly preserved asses of the Julio-Claudian period were found in the excavations. In addition, three Flavian coins can be ascribed to the period AD 69-96. By contrast, there are more coins from the 2nd century with 21 coins from the reign of Trajan through to Commodus (AD 98-192). It is interesting to note that until the presence of silver radiates in the middle of the 3rd century, all of the coins are of base metal. Asses and dupondii are dominant in the 1 st century, increasingly giving way to sestertii in the 2nd century, until the sestertius, dominant in the 3rd century. Remarkably, all the coins were minted at Rome.

\section{Discussion}

The discovery of a small Roman gridded settlement on the Vrina Plain has altered our perception of Butrint as a Roman town. To begin with this was not strictly a suburb so much as a bridgehead extension of the extra-mural settlement that expanded first beyond the Hellenistic walls of Butrint to the Vivari Channel, then to the south side of that channel. Conceived perhaps in the early years of the Augustan colony, this extension - judging from the archaeological evidence - only really took shape in the Flavian period. Interestingly, Abdy tentatively proposes on the bases of the abbreviation CCIB used on the revived Claudio-Neronian coinage that this suburb might have been the Colonia Campestris Iulia Buthrotum, the 'field colony'. ${ }^{33}$ Following this, judging principally from the ceramic-dated stratigraphical evidence the bridgehead community grew by stages over the following two centuries to become eventually a mirror image of the large channelside dwellings on the north side of the Vivari Channel. None of this should really surprise us.

31 Crowson and Gilkes 2007: 148-54.

32 Gilkes and Hysa 2011.

33 Abdy 2012: 93. 
Does this mean that the new settlement and its land occupied previously public areas, or that some fields were taken from previous late Republican landowners, marking gradual changes in the administration of Butrint coinciding with the Emperor Nero's increased interest in Butrint? ${ }^{34}$ Further excavations will be required to define such administrative changes. Abdy, however, has made the interesting case for magisterial stability in the colony between Augustan and Neronian times as the magistrate, Graecinus appears to have had a long career as a duumvir then a duumvir quiquennalis, 'the most prestigious civic office when the duoviri had to organize the five yearly tax census. Finally, he became the duumvir quinq tert, showing that he achieved the very top office of duumvir quinquennalis three times' ${ }^{35}$ Associated with the maritime villa at Diaporit by virtue of a tile stamp discovered in the excavations, ${ }^{36}$ there is no doubting his role in creating a stable evolution of the colony. Less certain is the impact on the settlement of the re-designation of this northern area of Achaia to the new province of Epirus under the Emperor Trajan at the beginning of the 2 nd century. ${ }^{37}$ With this re-designation, exploitation of the interior was systematically extended with the making of the new town of Hadrianopolis, near modern Gjirokastra and its own centuriated hinterland..$^{38}$

On the other hand, the broad outlines of the Romanisation of Butrint's hinterland are not unique in this area. A similar new development at the (north-facing) base of Phoinike (at the north end of Lake Butrint) was found by Luigi Maria Ugolini and has been mapped by Sandro de Maria's team in recent years. ${ }^{39}$ Like the Vrina Plain settlement the lower Phoinike settlement was laid out in the later 1st century $\mathrm{AD}$ with gravelled streets, ${ }^{40}$ and occupied until at least the 2 nd century before it became a necropolis. In this case the steep west flank of Phoinike separates the two parts of the town whereas at Butrint it was the Vivari Channel. Further afield, it is exactly at this time too that the Achaian colonies of Nicopolis, Patras and Corinth appear to have implemented intensive new farming regimes based upon centuriation for their associated territories. ${ }^{41}$ The new initiative at Butrint, then, was not exceptional; it belonged to a larger Roman programme to invest and of course tax Achaia. As Alcock pointed out, the size of any ancient city's demographic base proved an important factor in their sustainability; this would have been especially true for smaller centres such as Butrint. Knowing more about this 'base', not only in terms of the chronology of the dispersed villas and farms, but also in terms of

34 Alcock 1993: 16

35 Abdy 2012: 93.

36 Bowden and Përzhita 2004; Hansen 2009: 59.

37 Cabanes 1997: 120.

38 Giorgi and Bogdani 2012: 129. See also Vitti, Santoriello 1999, Shpuza 2016.

39 De Maria 2007: 183; Giorgi and Bogdani 2012: 118-20.

40 See Giorgi and Bogdani 2012: 120, fig. 6.

41 Cf. Alcock 1993: 132-45; Romano 2003. 
Fig. 5. The maritime villa at Diaporit looking across Lake Butrint (photo: Alket Islami) site histories, serves as an important variable in measuring the urban history of a seaport like Butrint. ${ }^{42}$

There can be little doubt that Butrint's expansion onto the Vrina Plain is an approximate measure of both an effort to boost the town's productive population as well as increasing prosperity. The first dwellings were modest by any standards, but the grid of gravel streets shows the city's intent. In terms of prosperity, the creation of a maritime villa at Diaporit in place of the earlier Hellenistic and Augustan arrangement is perhaps the most telling illustration of growing prosperity in this corner of Epirus (Fig. 5). At some point in the period of AD 40-80 - approximately at the time the Emperor Nero visited Greece - the Diaporit villa was rebuilt on a larger scale, and as Bowden observes: 'the orientation ......was completely altered in this phase so that the buildings faced directly towards Butrint, perhaps reflecting the increasing significance of the town in the eyes of its owner"43 (Fig. 6). Though not grandiose, this villa like the new town housing of Butrint, best illustrated by the property on the south-facing edge of the acropolis, ${ }^{44}$ echoed the colony's cultural ethos on this Grecian shore.

We should assume that the town was benefiting from its seaborne commerce and a growing population. A comparable suburb at Arelate (Arles) perhaps offers a hint of what was to be found at this bridgehead: essentially a mixture of commercial, public and domestic buildings as well as docks, granaries, production areas and

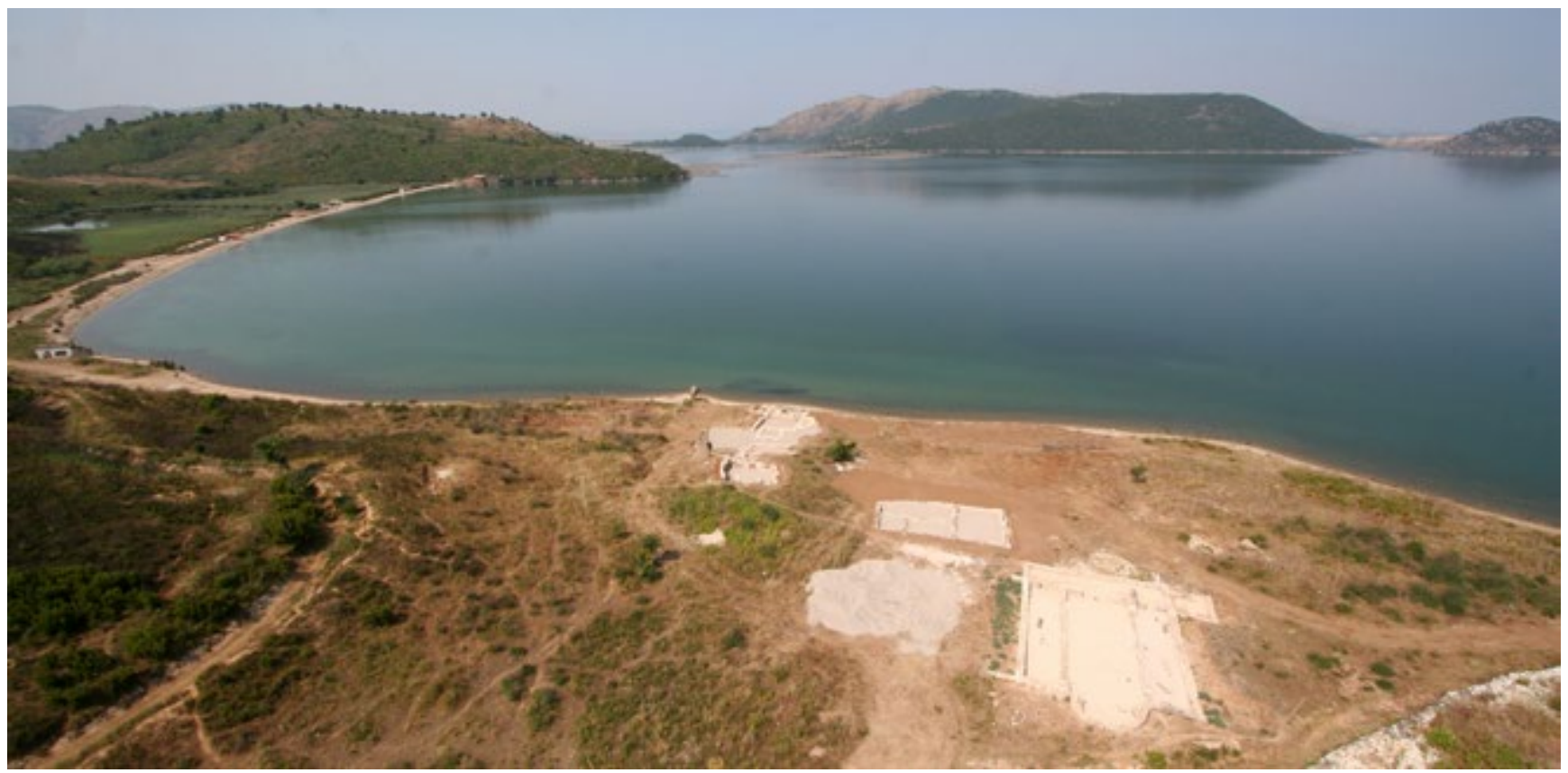

$42 \quad$ Alcock 1993: 171.

43 Bowden 2007: 205.

44 Greenslade, Leppard and Logue 2013: 53-55. 
portico-ed spaces associated with trades..$^{45} \mathrm{Here}$, in other words, was an intersection of agrarian, fishing, industrial and mercantile activities, all with an eye on connections across the Adriatic Sea to Italy.

The suburb was well placed to manage the landscape to the east as well as Butrint's affluent fishing-grounds. It was a quintessential, richly endowed, Roman microregion in the sense described by Horden and Purcell in their book, The Corrupting Sea. ${ }^{46}$ That this suburb altered over time, evolving into one or more moderately affluent villas before it became one large villa in the 3rd century is possibly more intriguing. What happened, we might now wonder, to those earlier bridgehead amenities from the generations following the colonial period? No ready answers are yet apparent.

Fig. 6. A plan of Diaporit in the 1st century $A D$ (drawn by Simon Greenslade)

This was the era during which monumental tombs were erected for the first time on the Vrina Plain and smaller tombs were also interred on Shën Dimitri alongside the earlier road. Neither area had been employed as a cemetery in the later Hellenistic period, unlike Phoinike where the new 1st-century AD lower town partly occupied an earlier Hellenistic cemetery. ${ }^{47}$ By Butrint standards neither cemetery -on the Vrina plain or on Shën Dimitri - is exceptional. Finer tombs lined the Vivari Channel west of the town ${ }^{48}$ and outside the Hellenistic-era Lion Gate. Richer cremation graves were also found by Ugolini on the elevated spur west of the West Gate of the town.

Butrint, of course, was not insulated from the greater economic changes occurring in the Empire and especially in Italy. Harbingers of the 3rd-century crisis in the port are perhaps to be found first beyond the bridge across the Vivari Channel. The desertion of the villa at Diaporit in the later 2nd century following constant alterations and aggrandisement to the complex throughout the preceding part of the century ${ }^{49}$ - and probably the desertion of other such properties within the hinterland of Butrint - coincided with marked changes to the suburb. The process appears to parallel that found to the south at Nicopolis where major villas were founded in the sha-

45 Droste 2003: 77-79.

46 Horden and Purcell 2000: 100-1.

47 De Maria 2007: 183.

48 Hernandez and Mitchell 2013.

49 Bowden and Përzhita 2004. 
dow of the town's defences as the number of rural sites declined. ${ }^{50}$ Urban living, it appears, was becoming more attractive, even if the overall economic prosperity of the urban centres in the region was beginning to stall, before actually declining. To document this process much more information is needed about the history of the farms within the old centuriated landscape. Presently, at Butrint these farms remain unknown. As for investment in pastoral activities or fishing, very little evidence exists notwithstanding the extensive scale of these excavations. Finally, what is now clear is that the suburb belongs to the moment when the Pax Romana appears to have extended its reach to just about every Mediterranean region and village. At Butrint the suburb was an extension that morphed into the centuriated landscape beyond.

The revolution that began here in Augustan times appears to have ended in the later 2 nd century when the bridgehead was transformed into a major property that went through further iterations as an ecclesiastical complex then an aristocratic central-place respectively in Late Antiquity and the Mid Byzantine periods, and with this the attached, highly controlled landscape gradually became detached from Butrint.

\section{Acknowledgements}

Special thanks to Simon Greenslade who directed the excavations on the Vrina Plain as well as to Sarah Leppard. Theirs was a peerless contribution to Buthrotan studies and I am most grateful to them as I have drawn much of this essay from their fine reports. My thanks, too, to Richard Abdy, Oliver Gilkes, David Hernandez, Paul Reynolds and Sam Morehead whose studies are incorporated in this synthesis. The project was part of the Butrint Foundation's research at Butrint in partnership with the Packard Humanities Institute as well as the Albanian Institute of Archaeology.

\section{References}

Abdy, R., 2012. 'Monuments, myth and small change in Buthrotum (Butrint) during the Early Empire', in The City and the Coin in the Ancient and Medieval Worlds. (BAR int. ser. 2402), edited by F. López-Sánchez. Oxford: Archaeopress, 91-101.

Alcock, S.E. 1993, Graecia Capta. The landscapes of Roman Greece, Cambridge: University Press.

Bescoby, D., 2007. 'Geoarchaeological investigation at Roman Butrint', in Roman Butrint. An Assessment, edited by I.L. Hansen and R. Hodges. Oxford: Oxbow Books, 95-118.

$50 \quad$ Wiseman 1998: 56-7. 
Bowden, W., 2020, (ed.), Butrint 5. Life and death at a mediterranean port. Oxford: Oxbow Books.

Bowden, W. and R. Hodges, ed. 2011. Butrint 3. Excavations at the Triconch Palace. Oxford: Oxbow Books.

Bowden, W. and L. Përzita. 2004. 'Archaeology in the landscape of Roman Epirus: preliminary report on the Diaporit excavations, 2002-3' in Journal of Roman Archaeology 17: 413-33.

Cabanes, P., F. Drini and M. Hatzopoulos. 2007, Corpus des inscriptions grecques d'Illyrie méridionale et d'Épire 2. Inscriptions de Bouthrôtos, Athens: École Française d'Athènes.

Cabanes, P., 1997. 'From the Roman Conquest to the Great Crisis of the Third Century A.D.', in Epirus. 4000 years of Greek history and civilization edited by M.B. Sakellariou. Athens: Demetrius and Egle Botzaris Foundation, 114-38.

Crowson, A., 2008, Venetian Butrint, London, Tirana: Butrint Foundation.

Crowson, A. and O.J. Gilkes. 2007. 'The archaeology of the Vrina Plain: an assessment', in Roman Burtrint: An Assessment edited by I. L. Hansen and R. Hodges. Oxford: Oxbow Books, 119-64.

De Maria, S. 2007. 'Butrinto e Fenice a confronto', in Roman Burtrint: An Assessment edited by I. L. Hansen and R. Hodges. Oxford: Oxbow Books, 175-88.

Deniaux, É., 1998, 'Buthrote, colonie romaine. Rescherches sur les institutions municipals', in Epigrafia romana in area adriatica edited by G. Paci. Pisa,Rome: Istituti Editoriali e Poligrafici Internazionali, 39-49.

- 2007, 'La structure politique de la colonie romaine de Buthrotum', in Roman Burtrint: An Assessment edited by I. L. Hansen and R. Hodges. Oxford: Oxbow Books, 33-39.

2009, 'Introduction', in Corpus des Inscriptions Latines d'Albanie edited by S. Anamali, H. Ceka and É. Deniaux. Rome: École française de Rome, 1-23.

Droste, M., 2003, Arles. Gallula Roma-das Rom galliens (Sonderbande der Antike Welt). Mainz am Rhein: Von Zabern.

Gilkes, O.J. and V. Hysa. 2011. 'In the shadow of Butrint', Expedition 54: 34-36.

Giorgi, E. 2017. 'Landscape and Citizens during the early Roman era in Northern Epirus: Phoinike and the Chaonia region (2nd BC-2nd AD)', in Groma 2. DOI: https:// dx.doi.org/10.12977/groma9

Giorgi, E and Bogdani, J. 2012. Il territorio di Phoinike in Caonia. Archeologia del paesaggio in Albania Meridonale. Scavi di Phoinike Serie Monografica I. Bologna: Ante Quem.

Greenslade, S. 2019a. ed. Butrint 6. Excavations on the Vrina Plain Volume 1. The Lost Roman and Byzantine Suburb, Oxford: Oxbow Books.

2019b. ed. Butrint 6. Excavations on the Vrina Plain Volume 2: the Finds, Oxford: Oxbow Books. 
Greenslade, S., S. Leppard, and Logue, M. 2013. 'The acropolis of Butrint reassessed', in Butrint 4. The Archaeology and Histories of an Ionian Town edited by I. L. Hansen, R. Hodges and S. Leppard. Oxford: Oxbow Books, 53-55.

Hansen, I. L. 2007. 'The Trojan connection: Butrint and Rome', in Roman Butrint: An Assessment edited by I. L. Hansen and R. Hodges. Oxford: Oxbow Books, pp. 44-6.

- 2009. Hellenistic and Roman Butrint (Butriniti Helenistik dhe Romak). London, Tirana: Butrint Foundation.

2011. 'Between Atticus and Aeneas: the making of a colonial elite at Roman Butrint', in Roman Colonies in the First Century of their Foundation edited by R. J. Sweetman. Oxford: Oxbow Books, 85-100.

- 2013, 'Roman sculpture from Butrint: a review of recent finds', in Butrint 4. The Archaeology and Histories of an Ionian Town edited by I. L. Hansen, R. Hodges and S. Leppard. Oxford: Oxbow Books, 105-122.

Hernandez, D. 2017a. 'Bouthrotos (Butrint)in the Archaic and Classical periods' in Hesperia 86: 205-71.

- 2017b. 'Buthrotum's sacred topography and the imperial cult, I: the west courtyard and pavement inscription' in Journal of Roman Archaeology 30: 99-126.

Hernandez, D. and Dh. Çondi. 2008, 'The Roman forum at Butrint (Epirus) and its development from Hellenistic to mediaeval times' in Journal of Roman Archaeology 21: 275-92.

. 2014, 'The formation of Butrint: new insights from excavations in the Roman Forum', in Proceedings of the International Congress of Albanian Archaeological Studies : 65th anniversary of Albanian archaeology (21-22 November, Tirana 2013) edited by L. Përzhita, I. Gjipali, G. Hoxha and B. Muka. Tirana : Centre for Albanian Studies and Institute of Archaeology, 285-302.

Hernandez, D. and J. Mitchell. 2013. 'The western cemetery: archaeological survey of Roman tombs along the Vivari Channel', in Butrint 4. The Archaeology and Histories of an Ionian Town edited by I. L. Hansen, R. Hodges and S. Leppard. Oxford: Oxbow Books, 182-201.

Hodges, R., E. Carr, A. Sebastiani and E. Vaccaro. 2016. "Beyond Butrint: The 'Mursi Survey', 2008" in Annual of the British School at Athens 115: 1-29.

Horden, P. and N. Purcell. 2000. The Corrupting Sea. A Study of Mediterranean History. Oxford: Wiley Balckwell.

Lane, A., D. Bescoby, O.J. Gilkes and S. O'Hara. 2004. 'The environs of Butrint 2: the 1995-96 environmental survey', in Byzantine Butrint: Excavations and Surveys 1994-99 edited by R. Hodges, W. Bowden and K. Lako. Oxford: Oxbow Books, 27-46.

Leppard, S. 2013. 'The Roman Bridge of Butrint', in Butrint 4: The Archaeology and Histories of an Ionian Town edited by I.L. Hansen, R. Hodges, and S. Leppard. Oxford: Oxbow Books, 97-104.

Morellón, M., F.S. Abselmetti, D. Ariztegui, B. Brushulli, G. Sinopoli, B. Wagner, L. Sadori, A. Gilli and A. Pambuku. 2016, 'Human-climate interactions in the central 
Mediterranean region during the last millennia: the laminated record of Lake Butrint (Albania)', Quaternary Science Reviews: 134-52.

Romano, D.G. 2003. 'City planning, centuriation and land division in Roman Corinth', in Corinth. The Centenary 1896-1996 edited by C.K. Williams and N. Bookidis. Princeton: American School of Classical Studies at Athens, 279-301.

Shpuza, S. 2016. La romanisation del l'Illyrie mèeridionale et de la Chaônie. Rome: École française de Rome.

Vitti, M. and A. Santoriello. 1999. 'Il paesaggio agrario del territorio della Colonia Victrix Philippensium', in Ancient Macedonia, 6th International Symposium, vol. 2, Institute of Balkan Studies, Thessalonikē : Hidryma Meletōn Chersonēsou tou Haimou, 987-1001.

Wilson, A.I. 2013. 'The Aqueduct of Butrint', in Butrint 4: The Archaeology and Histories of an Ionian Town edite by I.L. Hansen, R. Hodges, and S. Leppard. Oxford: Oxbow Books, 85-6.

Wiseman, J. 1998, 'Landscape archaeology in the territory of Nikopolis', in Foundation and Destruction. Nikopolis and Northwestern Greece edited by J. Isager. Athens: The Danish Institute at Athens, 43-63. 
